\title{
Thiol and urea functionalized magnetic nanoparticles with highly enhanced loading capacity and thermal stability for lipase in transesterification
}

\author{
Zeinab Salehi, Hamid Haghighat Ghahfarokhi, Abbas Ali Kodadadi", Rasoul Rahimnia \\ School of Chemical engineering, College of Engineering, University of Tehran, Tehran, Iran \\ khodadad@ut.ac.ir
}

\begin{abstract}
Magnetic nanoparticles (MNPs) were prepared by a co-precipitation method and thiol and urea functionalized using (3-mercaptopropyl) trimethoxysilane (MPTS) and 1-(3-trimethoxysilyl propyl) urea (TMSPU). The samples were characterized by SEM, XRD and FTIR, and BET surface area measurement and used for immobilization of Candida rugosa lipase type VII (CRL7) and Thermomyces lanuginosus lipase (TLL) for a transesterification reaction. The loading capacities of the lipases immobilized on the functionalized MNPs were also studied. The activity and thermal stability of the immobilized lipases were compared to those of the free enzymes too. The loading capacities of CRL7 and TLL on MNPs-TMSPU are 410 and 440 $\mathrm{mg} / \mathrm{g}_{-\mathrm{MNPs}}, 5.9$ and 5.5 times higher than those on the unfunctionalized MNPs, respectively. The initial activities of both CRL7 and TLL on MNPs-TMSPU are higher than those on MNPsMPTS. After $30 \mathrm{~min}$ incubation at $80^{\circ} \mathrm{C}$, the remained activity of TLL on MNPs-TMSPU is 2.5 times higher than that of the free enzyme. The remained activities of the biocomposites assayed after each use in transesterification reaction demonstrate that TLL-MNPs-TMSPU biocomposite has a high yield of 92\%. The immobilized TLL on MNPs-TMSPU and MPTS retain 80\% and $70 \%$ of their initial activities after 8 times reuse, respectively. The functionalized MNPs are magnetically separated for reuse.
\end{abstract}

Keywords: Lipase, Immobilization, Functionalized, Magnetic Nanoparticles, Transesterification. 


\section{Introduction}

The most important biocatalysts in synthetic organic chemistry are enzymes, which can promote the transformation of chemical species in living systems [1,2]. Enzymes are protein molecules with a wide range of compositions and complex structures and consist more than 20 types of amino acids [3]. Amio acids introduce different active functional groups including carboxylic acid $-\mathrm{COOH}$ (aspartic, glutamic), amin $-\mathrm{NH}_{2}$ (lysine), thiol $-\mathrm{SH}$ (cysteine) and hydroxyl $-\mathrm{OH}$ (serine, tyrosine) groups on enzymes, which can be used for covalent binding. The functional groups targeted for covalent attachment should be nonessential for the catalytic activity of the enzymes [3].

Lipases (triacylglycerol acylhydrolase, E.C.3.1.1.3 [4] or glycerol ester hydrolases [5]) are in an important group of enzymes with various biological activities including esterification between fatty acids and alcohols, triacylglycerols hydrolysis, and other enzymatic reactions. Lipases are widely used in the catalysis of reactions in industry [6]. Microbial lipases are commercially important because of lower production cost, wider availability, and greater stability than others. They may be produced from fungi, molds or bacteria. Most of the industrial microbial lipase is derived from fungi and bacteria. Fungi lipases are preferable, since they are usually extracellular, facilitating extraction from fermentation media, and the present day technology favors the use of batch fermentation and low cost extractive methods. The yeast Candida rugosa, and Thermomyces lanuginosus are industrial producers of lipases [7].

There are a number of problems in the practical use of enzymes, including the expensive isolation and purification, the instability of structures after separation from natural environments, sensitivity to process conditions, and inhibition by trace levels of substances. Therefore, using native enzymes as biocatalyst have some drawbacks [8]. These problems can be alleviated by the use of enzymes in immobilized forms, which allow the reuse of the biocatalysts for several times [9], resulting in reducing the costs and improving the quality of the products [10].

Immobilization is used as a key in the industrial processes to optimize the operational performance of an enzyme, particularly for use in non-aqueous media [11]. The immobilization can enhance the enzyme stability and process economics [12], allow the biocatalyst separation from products for continuous operation, and prevent the enzyme activity in subsequent process steps $[11,13,14]$. Various immobilization methods such as encapsulation, entrapment, crosslinking and covalent binding can be used $[5,12,15]$. Also immobilization of enzymes with cross 
linking on solid supports can increase thermal and operational stability, and recovery of enzymes. $[14,16]$ and covalent binding produce relatively stable immobilized enzymes with more reusability as compared to the physical adsorption methods [17]

Iron oxide magnetic nanoparticles are used for immobilization of enzymes and in biotechnology and medicine $[18,19]$. Some of advantages of iron oxide nanoparticles are superparamagnetism, easy separation in external magnetic fields [9], large surface-to-volume ratio and high surface area [20]. For the best performance of magnetic nanoparticles they should have typical sizes of 10-20 nm [21]. $\mathrm{Fe}_{3} \mathrm{O}_{4}$ nanoparticles are the most significant magnetic materials used in various applications, due to their super paramagnetic and catalytic characteristics [22]. MNPs surface is modified for moderate interaction with enzymes. Various techniques are used for modification of magnetic nanoparticles including direct conjugation of enzymes with organic molecules and metal-ligand complexes [23], surface-capping with small molecules such as dopamine derivatives and silane reagent [24], surface coating with a shell of polymer including polypyrrole, polyaniline[23], polydopamine, and poly(GMA)-grafted $\mathrm{Fe}_{3} \mathrm{O}_{4} / \mathrm{SiO}_{\mathrm{X}}$, entrapment of MNPs in a hydrophobic sol-gel material, and surface coating with inorganic (e.g. silica) shells [24].

Silane coupling agents can be used to form a durable bond between organic and inorganic materials. The general formula of silane coupling agents has two important parts of a hydrolyzable group and a nonhydrolyzable organic radical. Most of the widely used organosilanes have one organic substituent and three hydrolyzable substituents. In most surface modifications, the alkoxy groups of the trialkoxysilanes are hydrolyzed to form silanolcontaining species. Typical time for silane reaction is 4-12 hours and typical temperature is between 50 to $120^{\circ} \mathrm{C}[25]$.

In a study, trimethoxy-propyl, -octyl, and -octadecyl silanes were used for surface modification of magnetic nanoparticle for CRL immobilization on MNPs. The activity of immobilized lipase increased with increasing alkyl chain length of the alkyl group [26]. In another study, amineterminated magnetic beads activated by glutaraldehyde and sulfo-NHS/EDC were applied for immobilizing CRL. The immobilized lipase was used in kinetic resolution of (R,S)-ibuprofen. The immobilized lipase have good yield of enantioselectivity and conversion of the kinetic resolution of (R,S)-ibuprofen[27]. $\mathrm{Fe}_{3} \mathrm{O}_{4} / \mathrm{ZnO}$ core/shell magnetic nanoparticles were also modified with tetraethyl orthosilicate (TEOS) and functionalized with (3-Aminopropyl) 
triethoxysilane (APTES) then applied for immobilization of TLL. The immobilized enzyme exhibited high thermal, $\mathrm{pH}$, and operational stabilities [28]. And other researchers ues the APTES modified MNPs with glutaraldehyde for immobilizing CRL. CRL immobilized on APTES modified MNPs and activated by glutaraldehyde was able to be reused for 10 cycles with $90 \%$ residual activity at $55^{\circ} \mathrm{C}[29]$.

In this study, $\mathrm{Fe}_{3} \mathrm{O}_{4}$ magnetic nanoparticles were synthesized by a co-precipitation method, functionalized with two different silane agents of (3-mercaptopropyl) trimethoxysilane (MPTS) and 1-(3-trimethoxysilyl propyl) urea (TMSPU) containing thiol and amine groups and used for immobilization of CRL7 and TLL for transesterification reactions. The functionalization dramatically enhances the lipases loading capacity and thermal stability.

\section{Materials and methods}

\subsection{Materials}

Ferric chloride hexahydrate $99 \%\left(\mathrm{FeCl}_{3} \cdot 6 \mathrm{H}_{2} \mathrm{O}\right)$, ferrous sulfate heptahydrate $99 \%\left(\mathrm{FeSO}_{4} \cdot 7 \mathrm{H}_{2} \mathrm{O}\right)$, sodium carbonate $99 \%\left(\mathrm{Na}_{2} \mathrm{CO}_{3}\right)$, Urea $99 \%$, ammonia $25 \%$, sodium chloride $99 \%(\mathrm{NaCl})$, potassium chloride $99 \%(\mathrm{KCl})$, di-Sodium hydrogen phosphate $99 \%\left(\mathrm{Na}_{2} \mathrm{HPO}_{4}\right)$, potassium dihydrogen phosphate $99 \%\left(\mathrm{KH}_{2} \mathrm{PO}_{4}\right)$ and ethanol $99 \%$ were purchased from Merck and lipase from Thermomyces Lanuginosus (TLL solution, $\geq 100$ unit/mg), lipase from Candida rugosa Type VII (CRL7, $\geq 700$ unit/mg solid), p-nitrophenyl palmitate, (p-NPP), (3-Mercaptopropyl) trimethoxysilane $95 \%$ (MPTS), 1-(3-trimethoxysilyl propyl) urea (TMSPU) were purchased from Sigma-Aldrich.

\subsection{MNPs Synthesis and Characterization}

$\mathrm{Fe}_{3} \mathrm{O}_{4}$ nanoparticles were prepared by a co-precipitation method. $1.853 \mathrm{~g} \mathrm{Fe}_{2} \mathrm{SO}_{4} .7 \mathrm{H}_{2} \mathrm{O}, 3.604 \mathrm{~g}$ of $\mathrm{FeCl}_{3} \cdot 6 \mathrm{H}_{2} \mathrm{O}$ and $6 \mathrm{~g}$ of urea were dissolved in $50 \mathrm{~mL}$ deionized water to prepare a solution of iron ions with molar ratio of $2: 1\left(\mathrm{Fe}^{3+} / \mathrm{Fe}^{2+}\right)$. The solution was heated to $90^{\circ} \mathrm{C}$ for 10 minutes, to decompose urea and gradually increase $\mathrm{pH}$. Then the solution is cooled to room temperature and, while rigorously stirring, an aqueous solution of 3.5 M ammonium hydroxide was added drop wise to the iron ions solution at about $\mathrm{pH}$ 12. As the $\mathrm{Fe}_{3} \mathrm{O}_{4}$ nanoparticles were formed, the 
suspension became black. The precipitates were separated magnetically and washed several times with about $500 \mathrm{~mL}$ deionized water [30].

The agglomerate sizes of the magnetic nanoparticles were determined by a scanning electron microscope (SEM, KYKY EM - 3200) and the surface area was measured by the BET method, with CHEMBET 3000 instrument. Prior to BET measurement, the samples were degassed at $90^{\circ} \mathrm{C}$ for $2 \mathrm{~h}$. The FTIR spectra of the MNPs were obtained using an FTIR spectrophotometer (VECTOR 2000).

\subsection{Functionalization of MNPs}

MNPs were functionalized using silane coupling agents of (3-mercaptopropyl) trimethoxysilane (MPTS) and 1-(3-trimethoxysilyl propyl) urea (TMSPU) comprising thiol and urea functional groups, respectively. A modified method [31] was used for functionalization of magnetic nanoparticles. In brief, $0.65 \mathrm{~g} \mathrm{Fe}_{3} \mathrm{O}_{4} \mathrm{MNPs}$ and $0.1 \mathrm{~mL}$ MPTS were added to $25 \mathrm{~mL}$ ethanol. The reaction mixture was stirred at $120 \mathrm{rpm}$ for $24 \mathrm{~h}$ at room temperature. The resulting thiolfunctionalized MNPs (MNPs-SH) were then isolated by a magnet and washed several times with about $300 \mathrm{~mL}$ ethanol, to remove unreacted MPTS. The same procedure was used for urea functionalization of MNPs with TMSPU, except for toluene used as the solvent instead of ethanol.

The FTIR spectra of functionalized MNPs with MPTS and TMSPU were obtained, using the FTIR spectrophotometer.

\subsection{Enzyme Immobilization on the Functionalized MNPs}

For immobilization of TLL on the functionalized MNPs, $5 \mathrm{~mL}$ of a phosphate buffer solution containing $8 \mathrm{~g} \mathrm{NaCl}, 0.2 \mathrm{~g} \mathrm{KCl}, 1.44 \mathrm{~g} \mathrm{Na}_{2} \mathrm{HPO}_{4}, 0.25 \mathrm{~g} \mathrm{KH}_{2} \mathrm{PO}_{4}$, and $2 \%$ w/v lipase in $1 \mathrm{~L}$ deionized water was added to $5 \mathrm{~mL}$ aqueous solution of the functionalized MNPs with a concentration of $45.7 \mathrm{mg} / \mathrm{mL}$. The mixture kept at $25^{\circ} \mathrm{C}$ and stirred at $100 \mathrm{rpm}$ for $6 \mathrm{~h}(\mathrm{pH} \mathrm{7.0)}$. The immobilized enzyme was isolated by a magnet and washed several times with about $500 \mathrm{~mL}$ deionized water, to remove non-immobilized enzyme. Then the immobilized enzyme was dispersed in $0.05 \mathrm{M}$ buffer solution ( $\mathrm{pH}$ 7.0) to retain its maximum relative enzyme activity [32, 33]. The same method was applied for immobilization of both CRL7 and TLL lipases on the MNPs functionalized with MPTS and TMSPU. The amount of the loaded enzyme was measured by a UV-vis spectrophotometer (UNICO 2100) at $330 \mathrm{~nm}$ wave length, from the difference between the amount of the initial enzyme and its concentration in the wash-liquid [25, 34, 35]. 


\subsection{Lipase Activity Assay}

The lipase activity was determined by measuring the absorbance of p-nitrophenol (p-NP) as the hydrolysis product of p-nitrophenyl palmitate (p-NPP, $0.5 \% \mathrm{w} / \mathrm{v}$ in ethanol at $30^{\circ} \mathrm{C}$ ) at $410 \mathrm{~nm}$. One unit of the enzyme activity is defined as the amount of enzyme which catalyzed the production of $1 \mathrm{mmol} \mathrm{p}-\mathrm{NP} / \mathrm{min}$ under the experimental conditions [16].

\subsection{Thermal Stability Assay}

The effect of temperature on the free and immobilized lipase activity was determined by its incubation at $30-80^{\circ} \mathrm{C}$ for $30 \mathrm{~min}$. For example, $1 \mathrm{~mL}$ of the buffer solution with $2 \% \mathrm{w} / \mathrm{v}$ lipase and $1 \mathrm{~mL}$ of the buffer solution containing $82 \mathrm{mg}$ MNPs-SH-lipase were separately added to 1 $\mathrm{mL} 0.5 \%(\mathrm{w} / \mathrm{v}) \mathrm{p}-\mathrm{NPP}$ in ethanol. The solution was incubated at $30^{\circ} \mathrm{C}$ for $5 \mathrm{~min} .2 \mathrm{~mL}$ of $0.5 \mathrm{~N}$ sodium carbonate was added to terminate the reaction. After centrifuging at 10,000 rpm for 10 min, $0.5 \mathrm{~mL}$ of the supernatant was 10 -fold diluted with distilled water and the absorbance at 410 nm was measured with a UV-vis spectrophotometer [16].

\subsection{Transesterification Reaction}

Soybean oil $(5 \mathrm{~mL})$ and ethanol $(2.8 \mathrm{~mL})$ with a molar ratio of 1:3 was added into a $50 \mathrm{~mL}$ Erlenmeyer flask. Reaction was carried out in $1 \mathrm{~mL}$ pure hexane containing $500 \mathrm{mg}$ immobilized CRL7 or TLL in an orbital shaker (120 rpm) for $48 \mathrm{~h}$ at $35^{\circ} \mathrm{C}$ [36].

\subsection{Transesterification Reaction Yield}

For determining the yield of transesterification, the amount of glycerol released in the reaction catalyzed by the free and immobilized lipases was compared with that catalyzed by $\mathrm{NaOH}$ [36]. Homogenous base catalysts, such as $\mathrm{NaOH}$ and $\mathrm{KOH}$, can catalyze transesterification in a short reaction time of 20-60 min with high yield of $0.8 \mathrm{~g} / \mathrm{g}$ oil considered as $100 \%$ conversion [37]. Glycerol is formed only when the three positions of the triglyceride are attacked. The amount of glycerol released in the transesterification is measured by UV-vis spectrophotometer at $615 \mathrm{~nm}$ wave length $[36,38]$. By dividing the amount of glycerol produced in the transesterification on the lipase by that produced in the base catalyzed reaction, the enzymatic reaction yield is determined. 


\section{Results and Discussions}

\subsection{MNPs Characterization}

The SEM image of agglomerated MNPs powder is shown in Fig. 1. The average size of the agglomerates is $50 \mathrm{~nm}$. The BET surface area of the MNPs is $70 \mathrm{~m}^{2} / \mathrm{g}$, which corresponds to 17 $\mathrm{nm}$ particles, assuming spherical particles. Super paramagnetic property is observed for the MNPs sizes less than $20 \mathrm{~nm}[18]$.

Fig. 1 - SEM image of MNPs

Fig. 2 shows XRD patterns of the reference (I) and the synthesized $\mathrm{Fe}_{3} \mathrm{O}_{4}$ powder (II). Six characteristic peaks for $\mathrm{Fe}_{3} \mathrm{O}_{4}$ corresponding to (220), (311), (400), (422), (511) and (440) are observed in the sample [39].

Fig. 2 - XRD patterns of the reference (I) and the synthesized $\mathrm{Fe}_{3} \mathrm{O}_{4}$ powder (II)

\subsection{Functionalized MNPs FTIR Analysis}

FTIR is widely used to confirm the attachment of different functional groups in each step of the functionalization [21]. Fig. 3 shows the FTIR spectra of MNPs, MNPs-MPTS and MNPsTMSPU with their absorption bands assignments. A cursory inspection of the spectra shows two absorption bands below $1000 \mathrm{~cm}^{-1}$ as a common feature of all the ferrites. Absorption in this region is not restricted to this class of compounds but occurs in the spectra of most metal oxides [38]. The absorption broad bands near 3400 and $1630 \mathrm{~cm}^{-1}$ are ascribed to the vibration of remainder $\mathrm{H}_{2} \mathrm{O}$ in the samples [40, 41]. The absorption peaks around 563 or $580 \mathrm{~cm}^{-1}$ are the characteristic absorption of $\mathrm{Fe}-\mathrm{O}$ bond of magnetite nanoparticles [38]. The presence of $\mathrm{Fe}-\mathrm{O}-\mathrm{Si}$ bonds cannot be observed in the FTIR spectra, due to their appearance around $584 \mathrm{~cm}^{-1}$ and overlap with the Fe-O vibration of magnetite nanoparticles [31, 41]. The peaks at 1039,1105,994 are the characteristic peaks for the $\mathrm{Si}-\mathrm{O}, \mathrm{Si}-\mathrm{O}-\mathrm{H}, \mathrm{Si}-\mathrm{O}-\mathrm{Si}$ stretching bands, which indicate MPTS and TMSPU binding to the surface of MNPs [42]. The bands around 1600 and $3400 \mathrm{~cm}^{-1}$ are attributed to the $\mathrm{NH}_{2}$ bending of free $\mathrm{NH}_{2}$ group and $\mathrm{N}-\mathrm{H}$ stretching vibration, respectively [42, 43]. The amino groups are observed for MNPs-TMSPU in Fig. 3, confirming the urea functionalization of the MNPs surface. The absorption band at $2577 \mathrm{~cm}^{-1}$ can be ascribed to the $\mathrm{S}-\mathrm{H}$ stretching of MPTS moieties [31]. The absorption bands at $2920-2850 \mathrm{~cm}^{-1}$ are ascribed to 
the $\mathrm{C}-\mathrm{H}$ stretching vibrations, which is indicative the propyl group on the functionalized MNPs [44]. The data confirms the successful thiol and urea functionalization of MNPS with MPTS and TMSPU, respectively, by covalent bonds.

Fig. 3 - FTIR analysis of MNPs and the functionalized ones.

\subsection{Lipase Loading Capacity of Functionalized MNPS}

Table 1 shows the loading capacity of CRL7 and TLL on the MNPs and thiol and urea functionalized ones at $25^{\circ} \mathrm{C}$ and $\mathrm{pH}$ 7. As the MNPs are functionalized by MPTS, their loading capacity for CRL7 and TLL dramatically enhances by 4.6 and 4.5 times. Even higher loading capacity enhancements of 5.9 and 5.5 times are observed for CRL7 and TLL on MNPs-TMSPU, respectively. The $440 \mathrm{mg} / \mathrm{g}-\mathrm{MNPs}$ loading of TLL on MNPs-TMSPU is even higher than the highest value of $429 \mathrm{mg} / \mathrm{g}-\mathrm{MNPs}$ reported for polydopamine coated MNPs [34].

The electrostatic attraction between oppositely charged active amino groups on the MNPsTMSPU surface and carboxyl groups of the lipase can be the main cause of the lipases immobilization. On the other hand, reactions between the active thiol groups on the surface of the MNPs-MPTS and thiol groups of the lipase results in moderately strong disulfide bonds between the two. High loading capacity is a result of the strong interactions of the enzymes with the functional groups [34].

Table 1 - Lipase loading capacities of MNPs and the functionalized ones at $25^{\circ} \mathrm{C}$ and $\mathrm{pH} 7$

\begin{tabular}{l|cc}
\hline \multirow{2}{*}{ Enzyme Support } & \multicolumn{2}{|c}{ Loading Capacity } \\
\cline { 2 - 3 } & CRL7 & TLL \\
\hline MNPs & 70 & 80 \\
MNPs- MPTS & 320 & 360 \\
MNPs-TMSPU & 410 & 440 \\
\hline
\end{tabular}

Schematic of lipase immobilization steps on functionalized MNPs is shown in Fig. 4. The reaction between MNPs-TMSPU and MNPs-MPTS with lipase are spontaneous and rapid [34].

Fig. 4 - Schematics of lipase immobilization steps on the functionalized MNPs. 


\subsection{Immobilized Lipases Specific Activities}

The specific activities of the free lipases and the ones immobilized on MNPs-MPTS and MNPsTMSPU are presented in Table 2. Immobilized on MNPs-MPTS and MNPs-TMSPU, the CRL7 lipase shows 76.7 and $85.7 \%$, while TTL presents 82.4 and $87.9 \%$ of the activity of the free lipases, respectively. $87.5 \%$ of free CRL7 enzyme activity was observed, when the lipase was immobilized on polyacrylonitrile (PAN) nanofibrous membranes [45]. In another study, $88.1 \%$ activity of the free CRL7 was observed for the CRL7 immobilized on functional exfoliated graphene oxide [46]. Even lower activity of 60.4\% was reported for CRL7 immobilized on super paramagnetic nanoparticles $\mathrm{Fe}_{3} \mathrm{O}_{4} /(2$-hydroxyethty methacrylate-co-dimethyl dially ammonium chloride) copolymer with positive charge and active epoxy groups simultaneously [47]. Also TLL immobilized by both physical adsorption and covalent attachment onto polyglutaraldehyde activated styrene-divinylbenzene (STY-DVB) copolymer has also been studied [48]. TLL activity was $60 \%$ and $85 \%$ on the hydrophobic micro porous STY-DVB and polyglutaraldehyde activated STY-DVB-PGA copolymer, respectively.

Table 2 - Specific activity of immobilized enzymes

\begin{tabular}{c|cc}
\hline \multirow{2}{*}{ Enzyme } & \multicolumn{2}{|c}{$\begin{array}{c}\text { Specific Activity U/g } \\
\text { (Percent of remained activity) }\end{array}$} \\
\cline { 2 - 3 } & CRL7 & TLL \\
\hline \multirow{2}{*}{ MNPs- MPTS } & 27900 & 103300 \\
& $(76.7)$ & $(82.4)$ \\
MNPs-TMSPU & 31200 & 110250 \\
& $(85.7)$ & $(87.9)$ \\
Free Enzyme & 36400 & 125400 \\
& $(100)$ & $(100)$ \\
\hline
\end{tabular}

More than $50 \%$ of the native activity may reduce with immobilization of an enzyme on a support [49]. However, enzyme immobilization facilitates convenient enzyme handling, facile enzyme separation and recovery from products, and enhanced stability under storage and operational conditions (against e.g. denaturation by heat, organic solvents, or autolysis) [12]. The covalent immobilization highly affects the enzyme conformation [50] and possibly its secondary structure, or limits the accessibility of substrate to the active site of the enzyme [51]. The high specific activity of the immobilized enzyme shows that the active site and configuration of enzyme are less affected by the immobilization [50]. 


\subsection{Immobilized Lipases Thermal Stabilities}

The thermal stability of both the immobilized and free lipases is studied by their incubation at $30-80^{\circ} \mathrm{C}$ followed by measuring the lipase activity. The results are shown in Fig. 5 and 6 . The figures show that, at most temperatures, the remained activity of the immobilized lipases is significantly higher than that of the free enzyme. Higher losses of activity are observed for TLL on MNPs-MPTS incubated at temperatures higher than $50^{\circ} \mathrm{C}$. For all incubation temperatures, the remained activity of TLL immobilized on MNPs-TMSPU is higher than that of the free enzyme. For example, 2.5 times higher activity is observed for the TLL immobilized on MNPsTMSPU and incubated at $80^{\circ} \mathrm{C}$.

Fig. 6 presents that the remained activity of CRL7 immobilized on both MNPs-MPTS and MNPs-TMSPU and incubated at different temperatures in the range of $30-80^{\circ} \mathrm{C}$ are higher than the free enzymes. The highest activities are observed for CRL7 immobilized on MNPs-TMSPU.

Fig. 5 -Remained activity of the free and immobilized TLL lipase.

Fig. 6 - Remained activity of free and immobilized CRL7 enzyme.

Thermal stability of lipases depends on their structures [52]. In a process at a high temperature, because of unfolding and heat-induced destruction of non-covalent interaction in enzymes, many problems can be encountered. One of the main reasons for enzyme immobilization is the anticipated increase in its stability toward various deactivating forces, due to the enzyme restricted conformational mobility following the immobilization [11, 52]. The higher remained activity at higher temperatures means that the immobilized enzyme can be applied at higher temperatures and retain its activity [53]. The results of this study show a higher thermal stability for the immobilized lipases, due possibly to the proper interaction between the enzyme and the support. Therefore, enhanced thermal stability of immobilized lipase in this research suggests that the functionalized MNPs support provides a good temperature resistance for the enzyme. This interaction retains the conformation of the enzyme at high temperatures [52]. 


\subsection{Transesterification Yield}

The transesterification yield of the immobilized enzymes is shown in Table 3. Immobilization of both CRL7 and TLL on MNPs-TMSPU improves the transesterification conversion by 4\%, as compared to the ones immobilized on MNPs-TMPS. On the other hand, TLL immobilized on both TMPS and TMSPU shows 7\% higher conversions in transesterification reaction, in comparison to immobilized CRL7, at the same conditions. Findings of other researchers confirm our results. CRL7 in transesterification process has a lower conversion than TLL from different sources of oil and alcohols at various conditions [54]. This is due to the higher specific activity of TLL (more than 100,000 U/g) in comparison to CRL7 (38,000 U/g) [55].

Table 3- The transesterification yield of lipases immobilized on MNPs-MPTS and MNPs-TMSPU.

\begin{tabular}{c|cc}
\hline \multicolumn{3}{c}{ Transesterification Yield } \\
Enzyme & CRL7 & TLL \\
\hline Immobilized on MPTS & 81 & 88 \\
Immobilized on TMSPU & 85 & 92 \\
\hline
\end{tabular}

\subsection{Magnetic Isolation and Reuse}

The lipases immobilized on the functional MNPs can be magnetically separated from their suspension in the transesterification solution. Fig. 7 shows the activity of the biocomposites of TLL immobilized on MNPs-MPTS and MNPs-TMSPU after multiple cycles of magnetic separation and reuse. 20 and 30\% loss in the activity of TLL immobilized on TMSPU and MPTS, respectively, are observed after 8 cycles of separation and reuse. The decrease in the activity may be caused by aggregation and loss of particles during magnetic isolation, denaturation of enzyme, and the gradual loss of lipase from the MNPs [34].

Fig. 7 - The relative activity of TLL-MNPs-MPTS and TLL-MNPs-TMSPU biocomposits after cycles of reuse.

Fig. 8-Magnetic isolation of TLL immobilized on the functionalized MNPs. Photographs of an aqueous suspension of the lipase biocomposite before (left) and after (right) magnetic isolation in transesterification process 


\section{Conclusions}

Magnetic nanoparticles (MNPs) functionalized with thiol and urea groups are investigated for immobilization of two lipases of CRL7 and TLL from different sources and applied for a transesterification reaction. (3-Mercaptopropyl) trimethoxysilane (MPTS) and 1-(3trimethoxysilyl propyl) urea (TMSPU) are used for thiol and urea functionalization of MNPs, respectively. The thermal stability and recyclability of the nano-biocomposites are also studied. The silanes covalently bound to the MNPs. The lipases thiol and carboxylic groups are most probably covalently bond to the thiol and urea functionalized MNPs, respectively, at room temperature. The loading capacity of the lipases dramatically enhances by 4.5 to 5.9 times, as the MNPs are functionalized. The specific activity of the immobilized lipases declines by 12.1 to $23.3 \%$, as compared to that of the free lipases. However, the thermal stability of the lipases enhances by the immobilization. The remained activity of TLL immobilized on MNPs-TMSPU is 2.5 times higher than that of the free lipase, after incubation at $80^{\circ} \mathrm{C}$. The transesterification yield of the lipases immobilized on the MNPs-TMSPU are 4\% higher than those immobilized on MNPs-MPTS. Only 20\% loss of TLL lipase activity is observed after 8 cycles of magnetic separation and reuse.

\section{Acknowledgement}

The authors would like to gratefully thank from Iranian National Science Foundation (INSF) for the financial support of this project.

\section{References}

[1] M.T. Reetz, A. Zonta, V. Vijayakrishnan, K. Schimossek, Journal of Molecular Catalysis A: Chemical, 134 (1998) 251-258.

[2] K. Drauz, Enzyme catalysis in organic synthesis: a comprehensive handbook, John Wiley \& Sons, (2012).

[3] V.H. Perez, G.S. da Silva, F.M. Gomes, H.F. de Castro, Biochemical Engineering Journal, 34 (2007) 13-19.

[4] M. Szczęsna Antczak, A. Kubiak, T. Antczak, S. Bielecki, Renewable energy, 34 (2009) 1185-1194.

[5] Y. Ren, J. Rivera, L. He, H. Kulkarni, D.-K. Lee, P. Messersmith, BMC Biotechnology, 11 (2011) 1-8.

[6] R. Fernandez-Lafuente, Journal of Molecular Catalysis B: Enzymatic, 62 (2010) 197-212.

[7] R. Aravindan, P. Anbumathi, T. Viruthagiri, Indian Journal of Biotechnology, 6 (2007) 141.

[8] D.-H. Zhang, L.-X. Yuwen, Y.-L. Xie, W. Li, X.-B. Li, Colloids and Surfaces B: Biointerfaces, 89 (2012) $73-78$. [9] K. Jainae, N. Sukpirom, S. Fuangswasdi, F. Unob, Journal of Industrial and Engineering Chemistry, 23 (2015) 273-278.

[10] B.D. Ribeiro, A.M.d. Castro, M.A.Z. Coelho, D.M.G. Freire, Enzyme research, 2011 (2011).

[11] R.A. Sheldon, Advanced Synthesis \& Catalysis, 349 (2007) 1289-1307.

[12] D. Brady, J. Jordaan, Biotechnology letters, 31 (2009) 1639-1650.

[13] K.M. Polizzi, A.S. Bommarius, J.M. Broering, J.F. Chaparro-Riggers, Current opinion in chemical biology, 11 (2007) 220-225.

[14] V. Minovska, E. Winkelhausen, S. Kuzmanova, Journal of the Serbian Chemical Society, 70 (2005) 609-624. 
[15] V.R. Murty, J. Bhat, P. Muniswaran, Biotechnology and Bioprocess Engineering, 7 (2002) 57-66.

[16] S.-H. Chiou, W.-T. Wu, Biomaterials, 25 (2004) 197-204.

[17] M.L. Verma, M. Naebe, C.J. Barrow, M. Puri, PloS one, 8 (2013) e73642.

[18] K.M. Ponvel, D.-G. Lee, E.-J. Woo, I.-S. Ahn, C.-H. Lee, Korean Journal of Chemical Engineering, 26 (2009) 127-130.

[19] S. Gurunathan, Journal of Industrial and Engineering Chemistry, (2015).

[20] N. Ballav, H. Choi, S. Mishra, A. Maity, Journal of Industrial and Engineering Chemistry, 20 (2014) 4085 -

4093.

[21] M. Faraji, Y. Yamini, M. Rezaee, Journal of the Iranian Chemical Society, 7 (2010) 1-37.

[22] C.-C. Lin, J.-M. Ho, H.-L. Hsieh, Chemical Engineering Journal, 203 (2012) 88-94.

[23] C.W. Lim, I.S. Lee, Nano Today, 5 (2010) 412-434.

[24] C.G. Netto, H.E. Toma, L.H. Andrade, Journal of Molecular Catalysis B: Enzymatic, 85 (2013) 71-92

[25] B. Arkles, Morrisville: Gelest, (2004) 1-5.

[26] J. Wang, G. Meng, K. Tao, M. Feng, X. Zhao, Z. Li, H. Xu, D. Xia, J.R. Lu, PloS one, 7 (2012) e43478

[27] M.P. Marszałł, T. Siódmiak, Catalysis Communications, 24 (2012) 80-84.

[28] S. Ghasemi, M. Heidary, M.A. Faramarzi, Z. Habibi, Journal of Molecular Catalysis B: Enzymatic, 100 (2014)

121-128.

[29] X. Meng, G. Xu, Q.-L. Zhou, J.-P. Wu, L.-R. Yang, Food Chemistry, 143 (2014) 319-324.

[30] W. Jiang, H.C. Yang, S.Y. Yang, H.E. Horng, J.C. Hung, Y.C. Chen, C.-Y. Hong, Journal of Magnetism and Magnetic Materials, 283 (2004) 210-214.

[31] L.G. Bach, M.R. Islam, J.T. Kim, S. Seo, K.T. Lim, Applied Surface Science, 258 (2012) 2959-2966.

[32] S. Kanimozhi, K. Perinbam, Materials Research Bulletin, 48 (2013) 1830-1836.

[33] M. Khoobi, S.F. Motevalizadeh, Z. Asadgol, H. Forootanfar, A. Shafiee, M.A. Faramarzi, Biochemical Engineering Journal, 88 (2014) 131-141.

[34] Y. Ren, J.G. Rivera, L. He, H. Kulkarni, D.-K. Lee, P.B. Messersmith, BMC biotechnology, 11 (2011) 63.

[35] D. Han, P. Walde, P.L. Luisi, Biocatalysis and Biotransformation, 4 (1990) 153-161.

[36] R.C. Rodrigues, M.A.Z. Ayub, Process Biochemistry, 46 (2011) 682-688.

[37] P.T. Vasudevan, B. Fu, Waste and Biomass Valorization, 1 (2010) 47-63.

[38] R.D. Waldron, Physical Review, 99 (1955) 1727-1735.

[39] H.V. Tran, L. Dai Tran, T.N. Nguyen, Materials Science and Engineering: C, 30 (2010) 304-310.

[40] M. Ma, Y. Zhang, W. Yu, H.-y. Shen, H.-q. Zhang, N. Gu, Colloids and Surfaces A: Physicochemical and Engineering Aspects, 212 (2003) 219-226.

[41] L. Guang-She, L. Li-Ping, R.L. Smith Jr, H. Inomata, Journal of Molecular Structure, 560 (2001) 87-93.

[42] L.D. White, C.P. Tripp, Journal of Colloid and Interface Science, 232 (2000) 400-407.

[43] M. Yamaura, R. Camilo, L. Sampaio, M. Macedo, M. Nakamura, H. Toma, Journal of Magnetism and Magnetic Materials, 279 (2004) 210-217.

[44] R.A. Bini, R.F.C. Marques, F.J. Santos, J.A. Chaker, M. Jafelicci Jr, Journal of Magnetism and Magnetic Materials, 324 (2012) 534-539.

[45] S.-F. Li, W.-T. Wu, Biochemical Engineering Journal, 45 (2009) 48-53.

[46] V. Patel, H. Gajera, A. Gupta, L. Manocha, D. Madamwar, Biochemical Engineering Journal, 95 (2015) 62-70.

[47] X. Liu, L. Lei, Y. Li, H. Zhu, Y. Cui, H. Hu, Biochemical Engineering Journal, 56 (2011) 142-149.

[48] N. Dizge, B. Keskinler, A. Tanriseven, Biochemical Engineering Journal, 44 (2009) 220-225.

[49] A.S. Roger, ChemInform, 38 (2007).

[50] V.R. Murty, J. Bhat, P.K.A. Muniswaran, Biotechnology and Bioprocess Engineering, 7 (2002) 57-66.

[51] D.-G. Lee, K.M. Ponvel, M. Kim, S. Hwang, I.-S. Ahn, C.-H. Lee, Journal of Molecular Catalysis B: Enzymatic, 57 (2009) 62-66.

[52] E. Yilmaz, M. Sezgin, M. Yilmaz, Journal of Molecular Catalysis B: Enzymatic, 69 (2011) 35-41.

[53] N. Chalkias, Cornell University, (2007).

[54] L. Fjerbaek, K.V. Christensen, B. Norddahl, Biotechnology and Bioengineering, 102 (2009) 1298-1315.

[55] S.L. Sigma lipase assay. Sigma bulletin No 800. Sigma, MO. 


\section{Fig. 1}

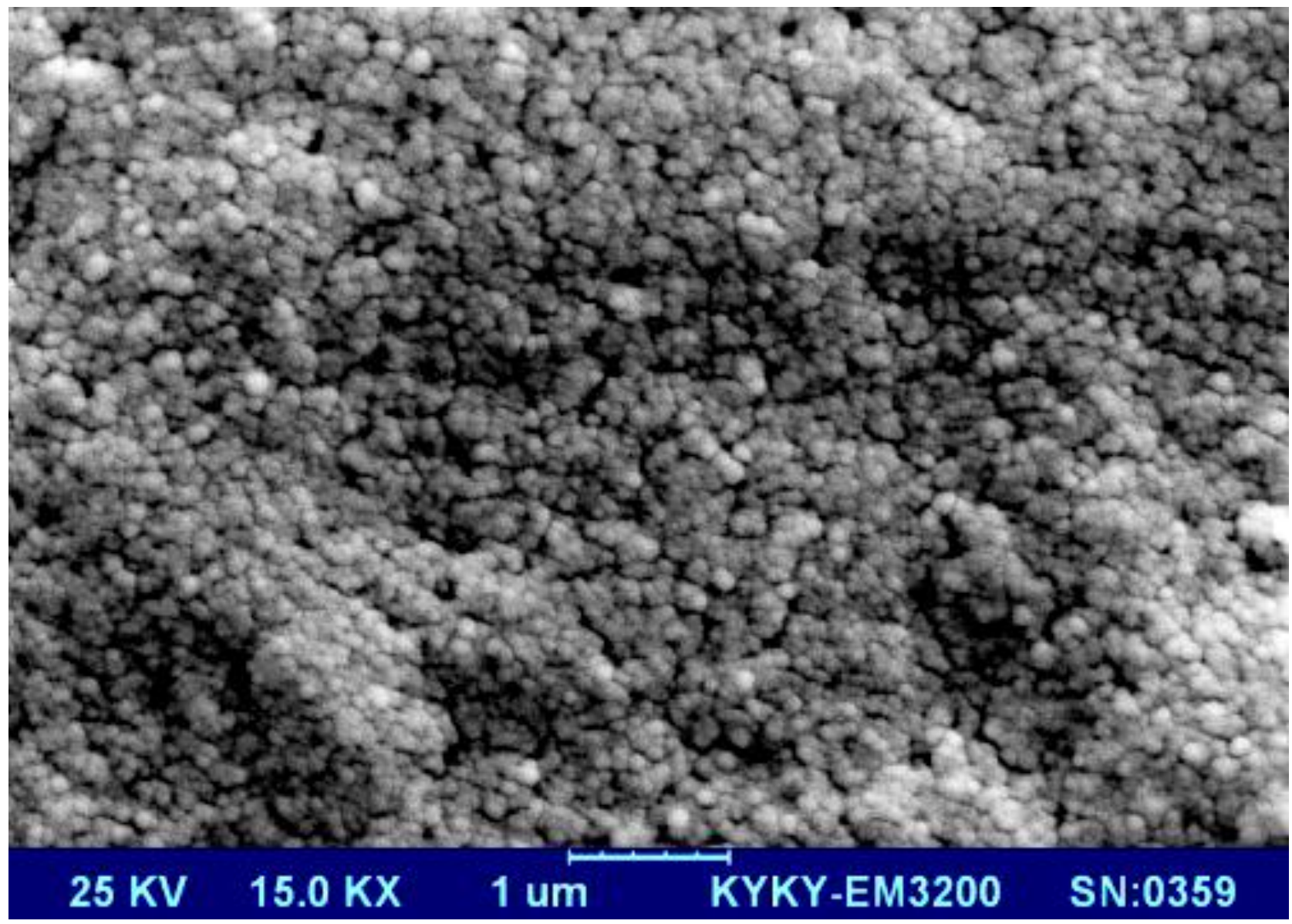


Fig. 2

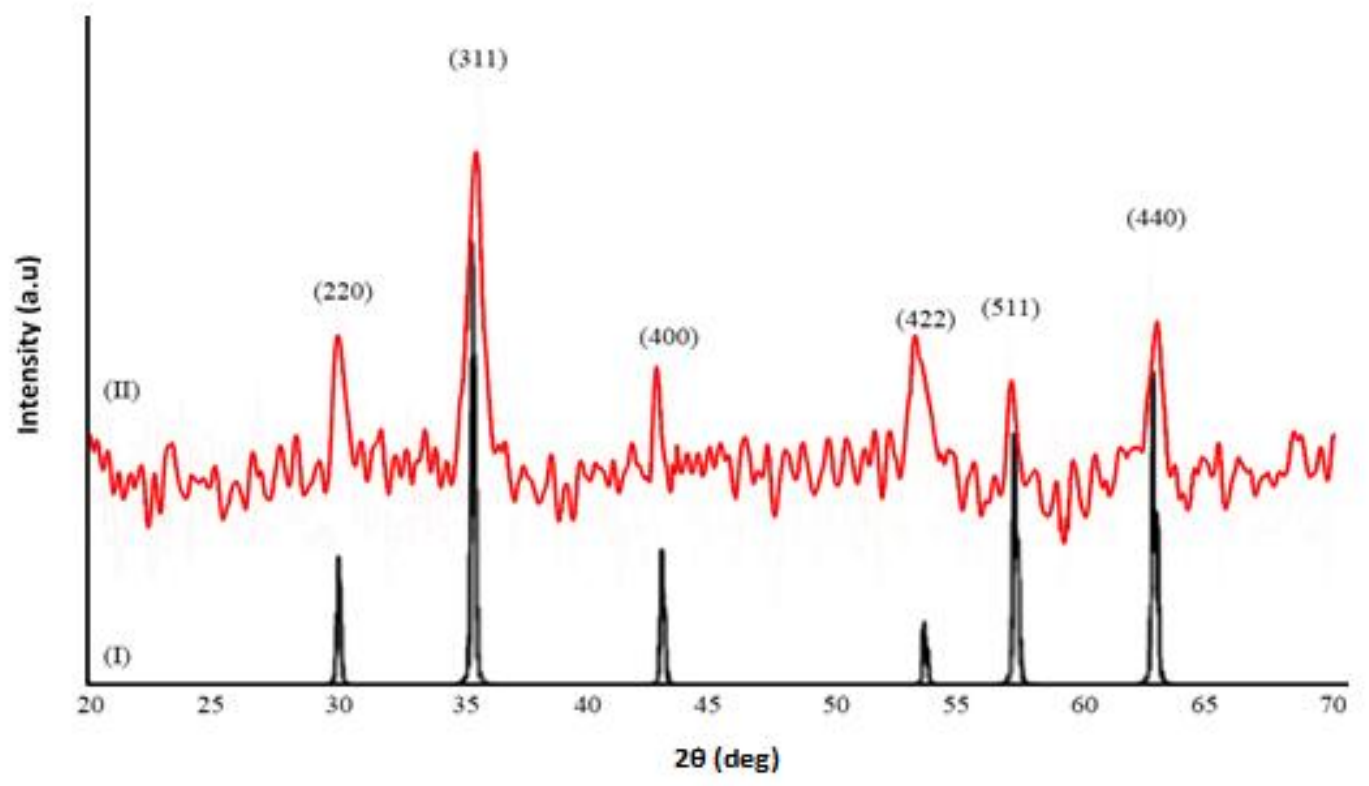


Fig. 3

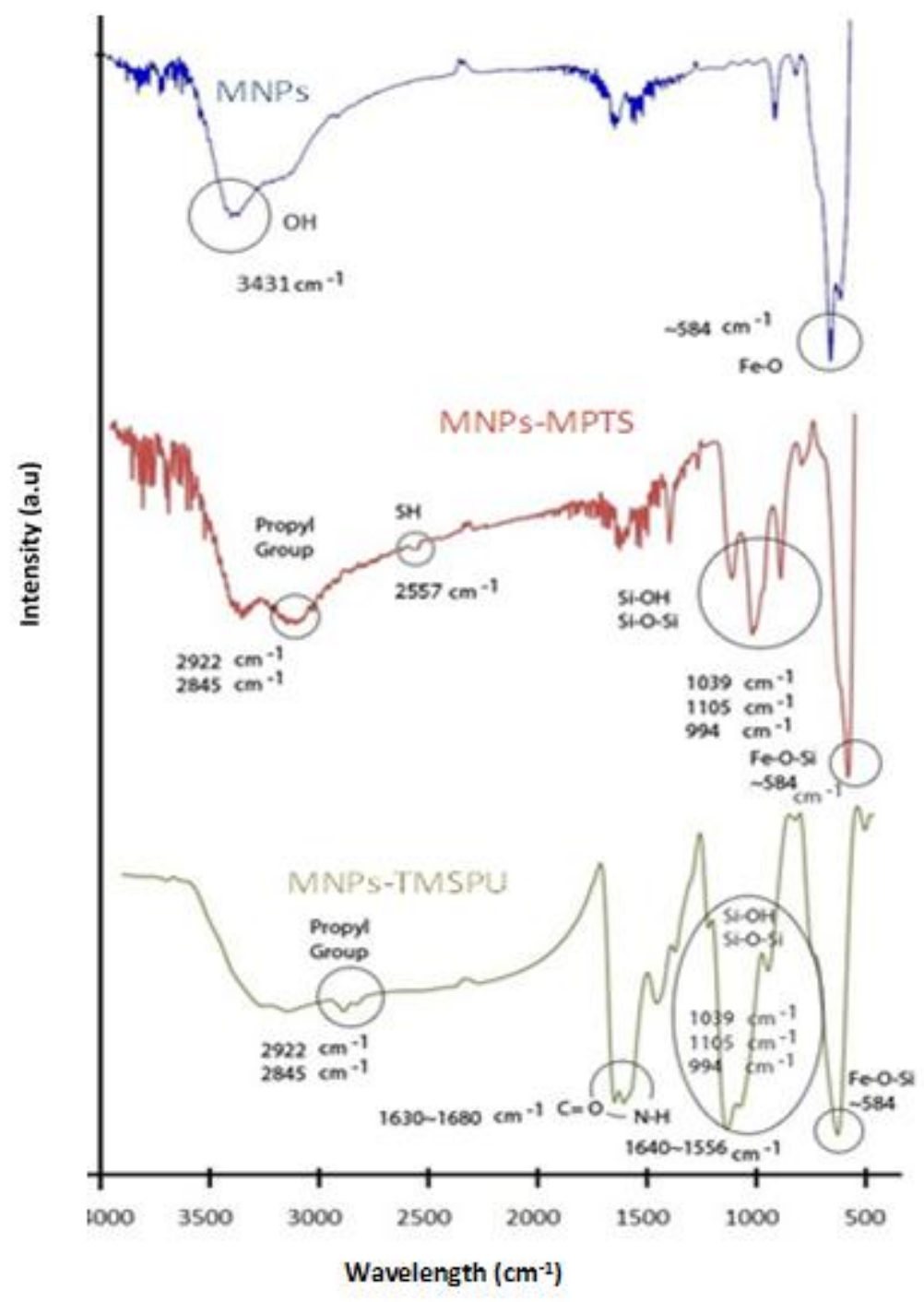


Fig. 4

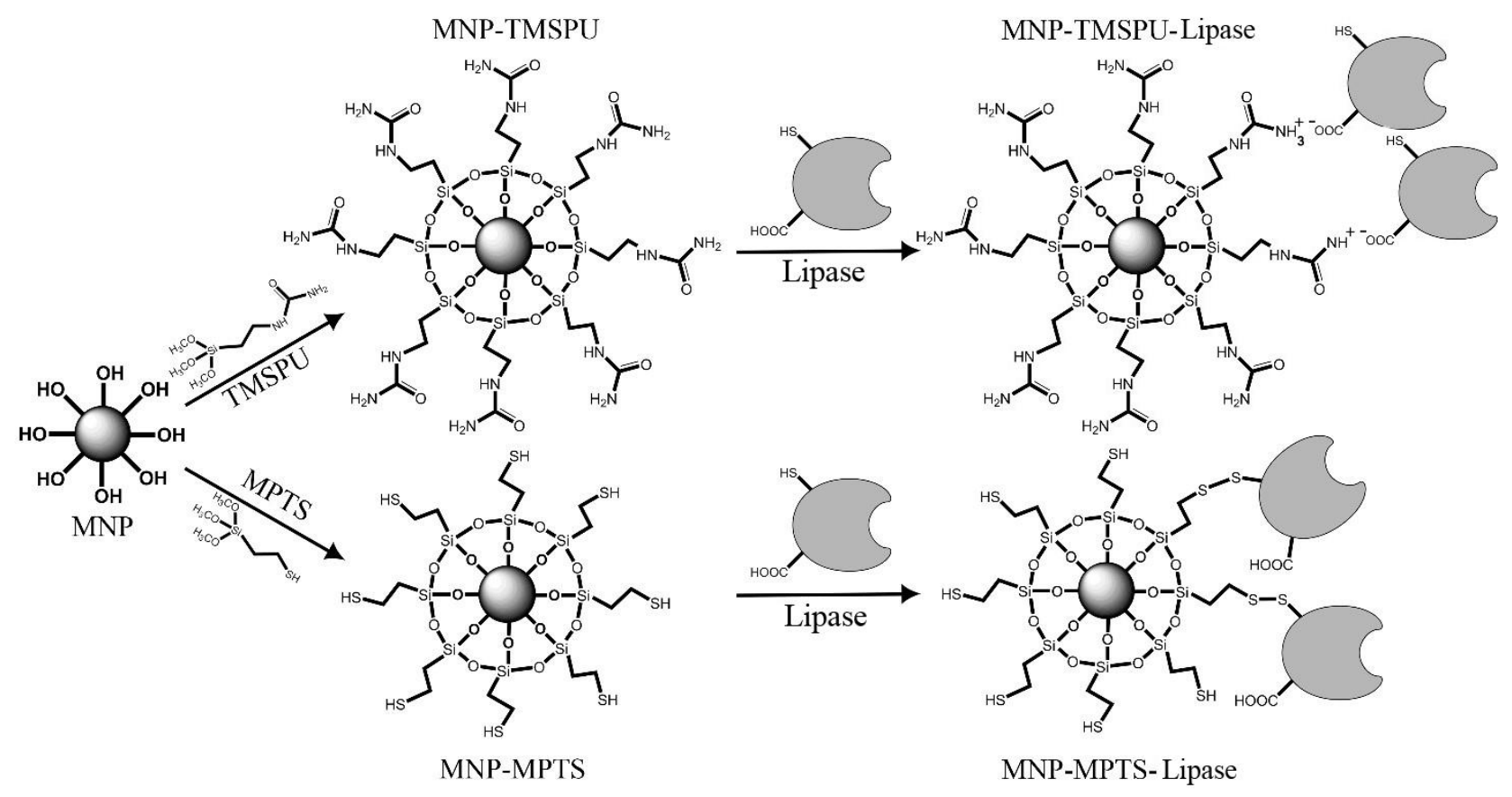


Fig. 5

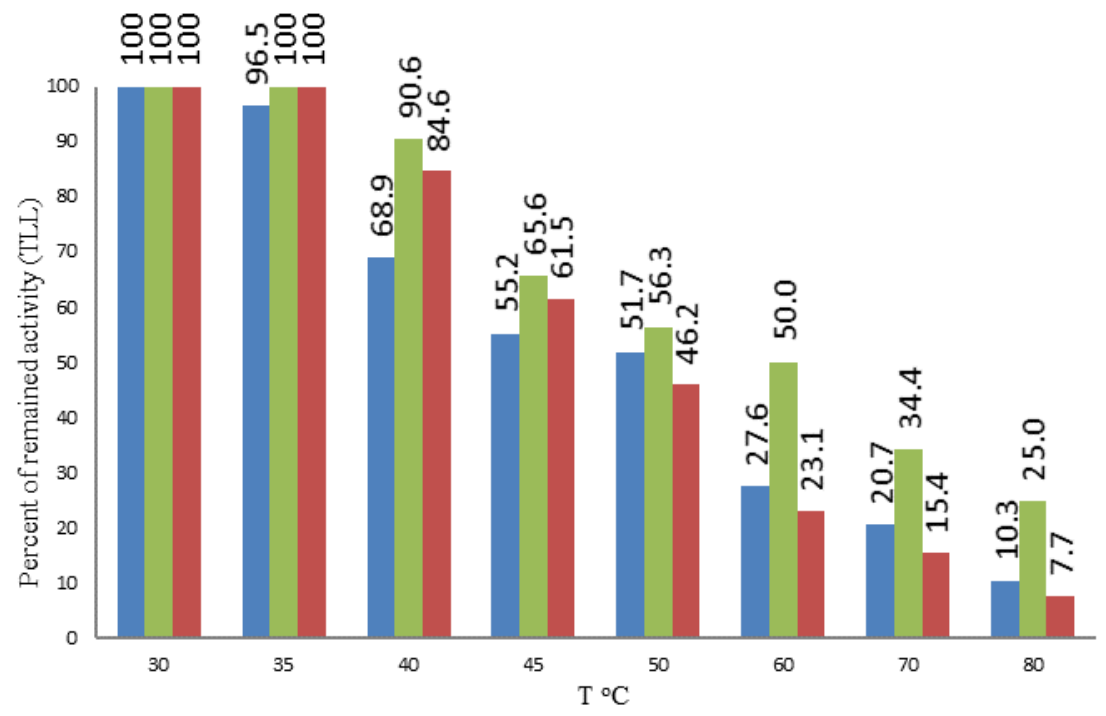

घree Enzyme Immobilized with TMSPU $\square$ Immobilized with MPTS 
Fig. 6

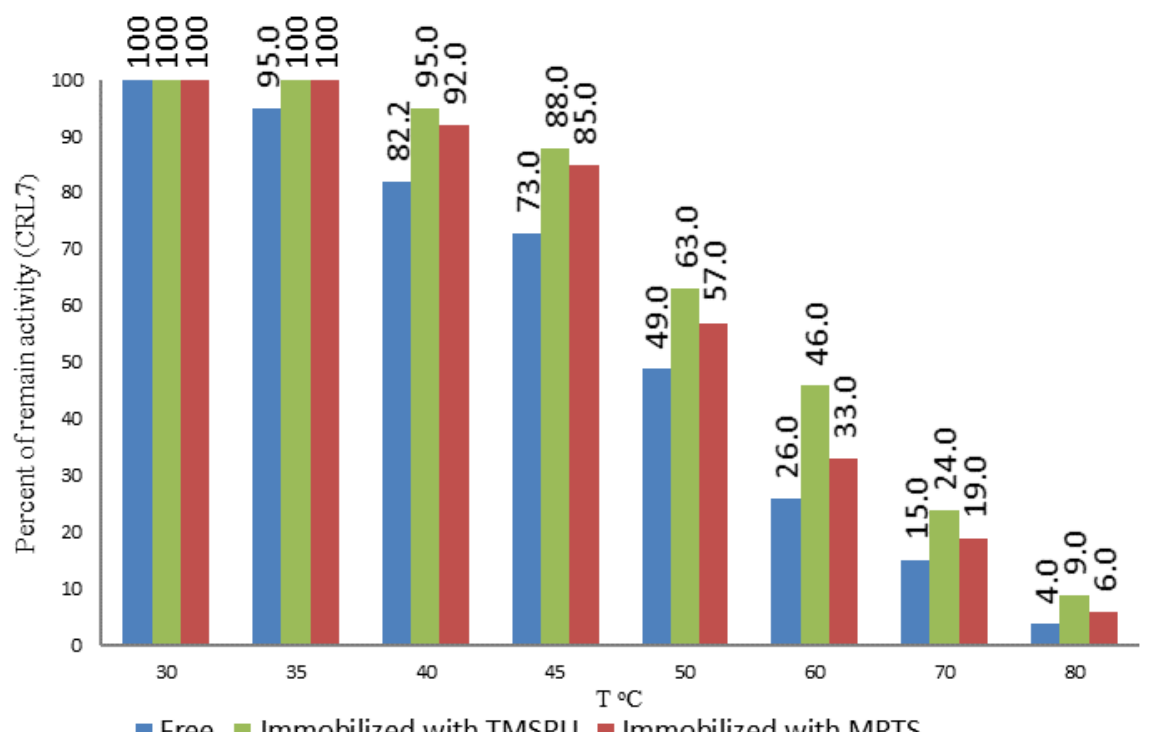


Fig. 7

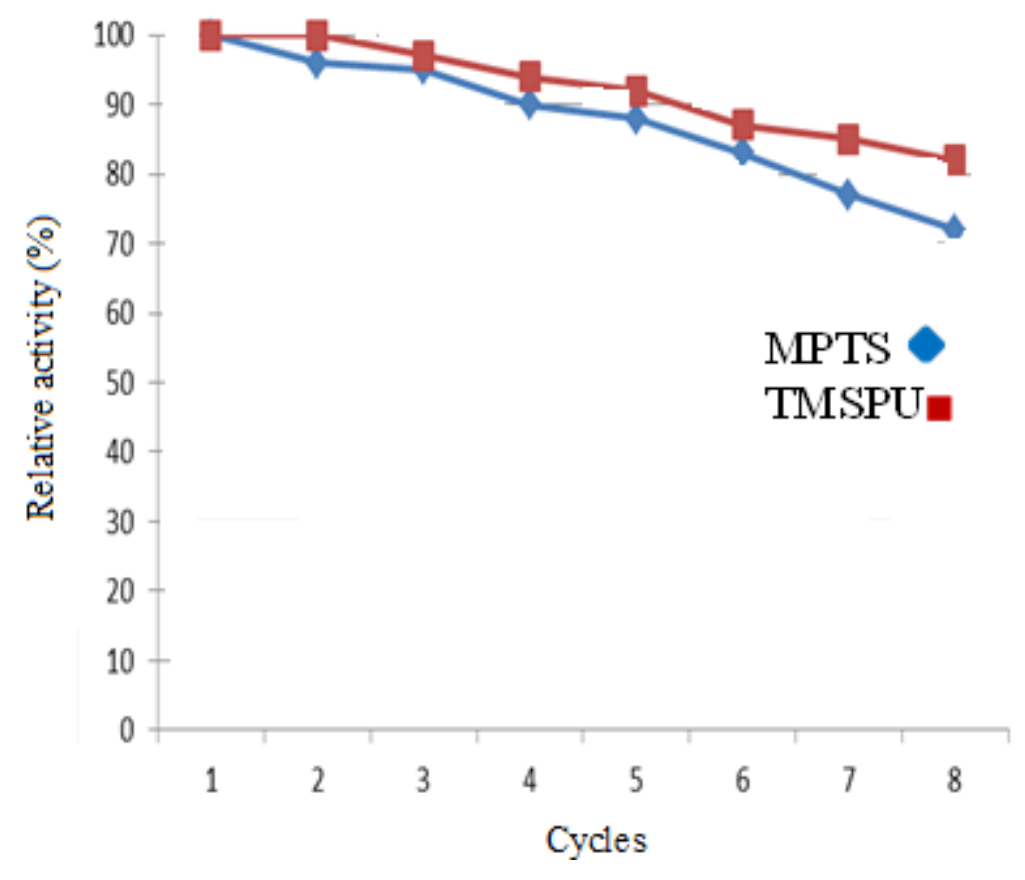


Fig. 8

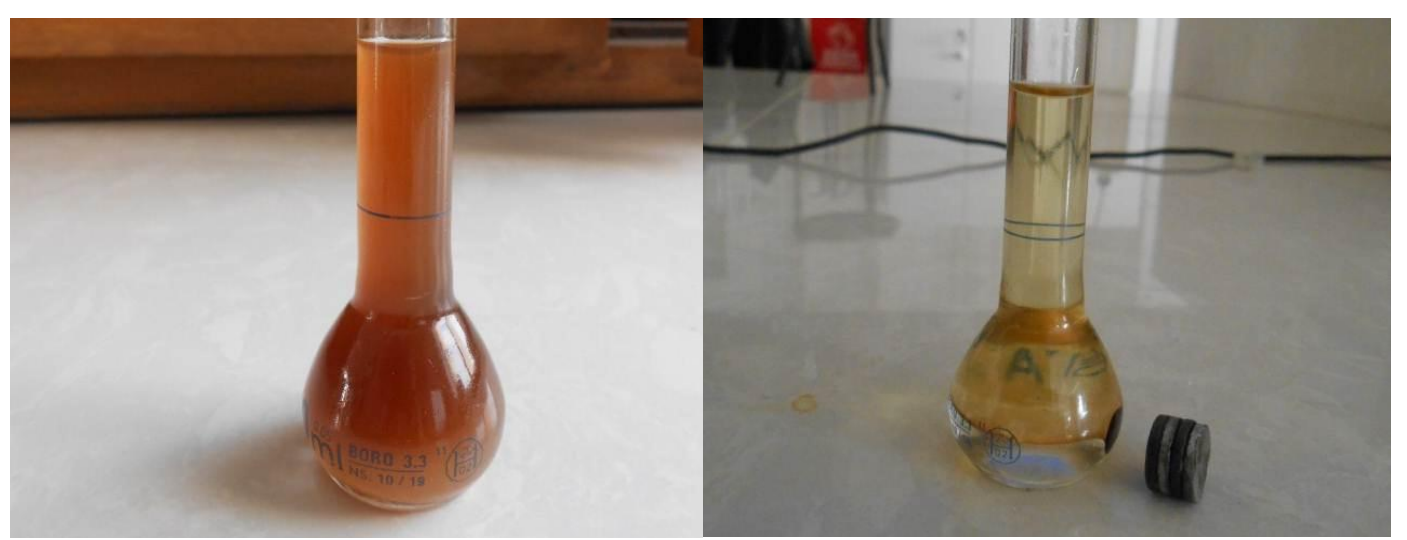

